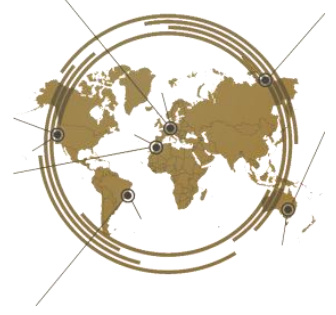

\title{
L2 Learning Online: Self-directed Learning and Gender Influence in Indonesian University Students
}

\author{
Adaninggar Septi Subekti* \\ ${ }^{1}$ English Language Education Department, Universitas Kristen Duta Wacana, Indonesia
}

The present study was conducted to investigate Indonesian second language (L2) learners' Self-Directed Learning (SDL) in English during the online classes due to the Covid-19 pandemic and to investigate whether there was a significant difference in SDL between female and male learners. As online learning is implemented nationwide in Indonesia due to the pandemic, it becomes paramount to investigate learners' SDL, considered very critical in online learning settings where teachers' ability to check learners' progress is not as extensive as it is in the face-to-face mode of instruction. The participants of the study were 187 undergraduate students taking English for Academic Purposes (EAP) classes. Through the data obtained from the online questionnaire, the study found that learners, in general, reported a high level of SDL even though many of them still embraced procrastination behaviours and considered the pragmatic need to pass the EAP class more important than the actual L2 learning. It also found that there was no significant difference between female learners' SDL and that of male learners. Based on the findings and analysis of the possible factors, possible contributions of the study are presented along with the possible limitations and suggested directions for future research in the field.

Keywords: Self-Directed Learning (SDL), gender, online learning

OPEN ACCESS

ISSN 25033492 (online)

*Correspondence:

Adaninggar Septi Subekti adaninggar@staff.ukdw.ac.id

Received: 11st October 2021 Accepted: 27 November 2021 Published:30th December 2021

Citation:

Subekti, A.S. (2021). L2 learning online: Self-directed learning and gender influence in Indonesian university students.

J. Eng. Educ. Society. 7:1. doi:10.21070/jees.v7i1.1427

\section{INTRODUCTION}

The Covid-19 pandemic has affected people's lives worldwide. Since its first appearance by the end of 2019 in the city of Wuhan, China, this pandemic has infected more than 170 million people across the globe with more than 3.53 million deaths among them as of May 2021. Due to the severity of the pandemic, governments worldwide have implemented closures to schools and universities since March 2020. Instructions were since then moved from face-to-face mode to distant mode mainly with the help of internet technology to stop or minimise the possible spread of the virus at schools or universities (Mondol \& Mohiuddin, 2020). Specific in the Indonesian context, the Indonesian government through the Ministry of Education and Culture with "Safety and Health First" policy has stated that distant learning is to be continued in all levels of education, including tertiary level until the pandemic situation could be contained (Kemendikbud, 2020).

Despite all the possible challenges of online learning especially at the time of the Covid19 pandemic, many authors have reiterated the potential benefits of online learning. Plaisance (2018) explained that online learning could be delivered synchronously or asynchronously. The synchronous mode enables real-time communication between teachers and learners (Plaisance, 2018) through teleconference applications such as Skype, Zoom, Microsoft Teams, and Google Meet. 
In comparison, in the asynchronous mode learners work on the given tasks within a flexible time parameter (Plaisance, 2018) through Learning Management System applications (LMSs) like Schoology, Moodle, and Google Classroom. Online learning further allows learners to learn L2 in a free virtual environment per their pace and time (Lee et al., 2016) especially in the context of the asynchronous mode. Plaisance (2018) further argued that the flexibility of online learning could be capitalised by the balanced and careful combination of synchronous and asynchronous modes of instruction and thus such practice tends to be more preferred by learners (Milligan \& Littlejohn, 2014 Moorhouse, 2020; Plaisance, 2018). In the case of adult learners such as those at the tertiary level of education, learners tend to have a strong belief of what works for them in learning and how they want to learn (Slaouti et al., 2013) and this could function as a powerful filter whether or not, or to what extent, such learners can optimally learn in the online learning context.

The mentioned preference is closely related to learners' psychology. It is argued that the psychology of L2 learners also takes an important role in the L2 learning process (Kim \& Kim, 2016) and it affects learners' various ultimate L2 achievements (Dornyei, 2005). These factors are collectively known as Individual Differences (IDs) (Dornyei, 2005; Ortega, 2009). Among more well-researched constructs of IDs such as L2 learners' aptitude, motivation, learning strategies, and anxiety, there are two constructs that, even though less researched so far, could be equally important. Those are L2 learners' self-directed learning (SDL) and gender.

\section{Self-directed learning (SDL) in an online L2 learning setting}

During the instruction process, traditionally principal decisions are made by teachers regarding such issues as what learners learn, how they learn, and how they understand the learning aims (Ayyildiz \& Tarhan, 2015). However, in the active learning context, learners are in charge of their learning and make decisions for themselves (Ayyildiz \& Tarhan, 2015). Active learning requires learners to self-direct themselves in deliberate and planned learning (Basereh \& Pishkar, 2016), thus the term self-directed learning (SDL).

In the context of instruction, SDL means that learners can "take initiative, with or without the teacher, in making decisions concerning their learning." (Sze-yeng \& Hussain, 2010, p. 193). In line with the definition of SDL, self-directed learners have specific attitudes, characteristics, and skills. They have the attitude of believing that learning is a personal responsibility, they engage in challenging problems, and they have the eagerness to learn, at times, despite the possible challenges (Ayyildiz \& Tarhan, 2015). These learners also have the skills to determine their learning goals and to select appropriate learning strategies. They are also able to distinguish between what is important and what is not, have good time management, and can monitor their ongoing achievements and to assess their study efficiency (Ayyildiz \& Tarhan, 2015).

SDL has been a subject of numerous empirical studies in various learning contexts (Ayyildiz \& Tarhan, 2015; Ko, 2018; Park et al., 2018; Rashid \& Asghar, 2016; Uz \& Uzun, 2018), suggesting researchers' acknowledgement of the role of SDL towards learning. Specific about SDL concerning technology use, Park et al.'s (2018) study in Korea, for example, found that learners' self-directed English learning ability was significantly correlated with their attitudes toward the internet. That means the more positive attitude they had towards the uses of the internet, the higher their SDL. Rashid and Asghar (2016) found the use of technology was strongly associated with Saudi Arabian learners' SDL whilst Uz and Uzun (2018) found through their experimental study that the experimental group experiencing a blended learning mode of instruction reported higher SDL than the control group experiencing face-to-face instruction. A study by Sumuer (2018) in Turkey further found that with adequate support and carefully designed online learning such as one offering flexible design and collaboration opportunities, learners could be facilitated to be in charge of their learning.

Despite the advantages, online learning also inherently has several challenges for learners. Concerning online learning due to the Covid-19 pandemic, Mondol's and Mohiuddin's (2020) study in Bangladesh reported that their participants faced various learning difficulties during the online learning because of limited internet credits, weak internet connectivity at home, and the unavailability of supporting gadgets. Furthermore, teachers' limited ability to check learners' understanding through visual indicators even in a synchronous mode of instruction (Plaisance, 2018) could lead to learners' prolonged misconceptions unless learners willingly ask questions or independently study further. The temporal and spatial freedom supposed to be the benefits of online learning, especially in the case of the asynchronous mode of instruction, could at the same time be a weakness (Plaisance, 2018). For example, learners procrastinate or keep postponing working on tasks and eventually put minimum efforts to finish them at the last moments (Klingsieck, 2013). The procrastination phenomenon was found to be prevalent among undergraduate students (Ozer, 2011). Hence, unless executed carefully, online learning could lead to possible learners' disengagement and disconnection from instruction (Plaisance, 2018).

With that in mind, it becomes sensible that learners' SDL become of critical importance in online learning settings (Zhu et al., 2020). Though not specifically in L2 literature, Allam et al.'s (2020) recent study in Malaysia during the beginning of the Covid-19 triggered online learning found that their university undergraduate student participants had a low level of SDL. Due to the Covid-19 pandemic and so the relatively abrupt shift to the online mode of instruction, learners were probably not fully ready to self-direct themselves to succeed in online learning settings. It is posited that unless learners have a high SDL level, they are unlikely able to optimally succeed in online learning settings (Zhu et al., 2020).

Specific in the Indonesian context, furthermore, empirical studies involving a large number of participants with the possibility of generalisation on learners' SDL in the context of online learning, to the best of my knowledge, are very rare. With the implementation of online learning nationwide and various challenges Indonesian learners may have related to infrastructure and resources, the issue of SDL in the context of online L2 learning can be paramount. Hence, it could be worthwhile conducting a study that could potentially shed a light on this field in the Indonesian online learning context at the time of the Covid-19 pandemic. 


\section{Gender influence in L2 learning}

There has been a commonly held belief that language learning is a feminine domain (Clark \& Trafford, 1995; Graham \& Rees, 1995; Lu \& Luk, 2014; MacIntyre et al., 2002). Female learners were found to show more positive attitudes towards learning such as higher motivation (Polat, 2011) and integrative motives

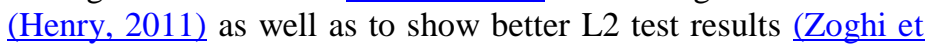
al., 2013). However, a study by Venkatesh and Morris (2000) found that when learning demands learners to master technological tools, male learners tended to show more effort than female learners did. Specific in the field of SDL, the gender aspect has been studied several times in different learning contexts (e.g.: Gokcearslan, 2017 in Turkey; Lee et al., 2017 in Hong Kong). Both studies, contrary to the previous studies favouring female learners in language learning, found that there was no meaningful difference between female and male learners' SDL in L2. This could indicate that albeit learners' gender plays a role in L2 learning (MacIntyre et al., 2002), the relationship between learners' gender and their L2 learning was not really straightforward. Hence, a further study investigating the relationship between learners' gender and their SDL is deemed strategic to be conducted. From the results, teachers could design instruction that in its way could best benefit learners of both genders.

With the mentioned rationales, the present study seeks to answer these research questions. First, what is L2 learners' level of SDL in English online class? Second, is there any significant difference between female learners' SDL and male learners'?

\section{METHODS}

\section{Research design}

The study used quantitative methods by distributing a questionnaire. The questionnaire consisted of several items on demographic information and fifteen items on SDL. The fifteen questionnaire items on learners' SDL were adapted from Ayyildiz's and Tarhan's (2015) Self-Directed Learning Skills Scale (SDLSS). Ayyildiz and Tarhan (2015) specifically conducted their study to develop a valid and reliable scale measuring SDL, later named SDLSS. The SDLSS had the Cronbach's alpha value of .86 indicating reliability (Ayyildiz \& Tarhan, 2015), which was the main reason of the adaptation of the scale in the present study. The original SDLSS measures learners' SDL in general irrespective of subjects and as such out of 40 items in the original SDLSS, only 15 items were used in the present study as these fifteen selected items were considered applicable in the context of L2 learning. These fifteen items were also slightly modified in the wording to further match the L2 learning context. For example, "I believe that I can learn a lesson, no matter how it is complicated" in the original SDLSS were slightly modified into "I believe that I can learn English, no matter how it is complicated." The participants were to respond with one of these responses: "Strongly agree" (equal to 5 points), "Agree" (4 points), "Neither agree nor disagree" (3 points), "Disagree" ( 2 points) and "Strongly disagree" (1 point). Item numbers 8 and 15 indicating negative statements were reversed scored. In these items "Strongly agree" signified low SDL whilst "Strongly disagree" signified high SDL.

The questionnaire was translated into the Indonesian language, with which language the participants were more proficient to facilitate the participants' better understanding on the questionnaire items and so generating more valid responses. The questionnaire was then made in Google Form.Before distributed, the questionnaire was piloted to several volunteers to make sure that all the items were "accurate, unambiguous, and simple to complete" (Gray, 2014, p. 372). After I did the necessary revisions based on feedback, the questionnaire was then distributed to the participants with the help of the class teachers from 20 October 2020 up to 6 November 2020. The fifteen items of the questionnaire had .78 Cronbach's alpha coefficient indicating that the questionnaire had a quite high internal reliability.

\section{Research participants and ethical considerations}

The present study's participants were 187 Indonesian undergraduate students taking English for Academic Purposes (EAP) in their respective departments at a private university in Java, Indonesia. These learners filled the Google Form SDL questionnaire. The selection of EAP class students as the participants of the present study was based on several considerations. Before taking EAP classes in their respective departments, these learners had already completed three noncredited General English (GE) courses, namely GE levels 1, 2, and 3, during three semesters. Hence, these learners had experienced English classes at the university level for three semesters before taking the EAP classes. Thus, they were considered having familiar with English instruction at the university level when participating in the study. Secondly, the EAP classes they were taking were the progression of the GE courses, thus had a higher difficulty level than that of GE courses. In such a context, coupled with the online learning setting due to the Covid-19 pandemic, these EAP learners' levels of SDL could play a vital part in their L2 learning.

The online instruction in these EAP classes was conducted in various ways depending on the teachers and the departments. However, typically, the teachers used the combination of the synchronous mode through Zoom, Google Meet, or Microsoft Teams, and asynchronous mode through tasks given through LMSs such as Google Classrooms or Moodle. Instant communications between teachers and students were mainly conducted through WhatsApp groups.

The present study employed the principles of research ethics. After gatekeepers' consent (Creswell, 2014) was obtained through the Heads of Department, I gave the link of the Google Form questionnaire to the respective class teachers for them to share with their respective EAP learners. The learners were given freedom whether or not to participate in the study to maintain the principle of autonomy (Israel \& Hay, 2006). Furthermore, at the beginning of the Google Form questionnaire, information about the objectives of the research, and participants' rights of voluntary participation (Oliver, 2003) was provided. All questionnaire data were solely used for the research purpose. Of the 187 participants in total, 87 participants (46.5\%) were willing to be invited for possible follow-up studies 
if necessary, indicating their enthusiasm in participating in the current research further. The other 100 participants $(53.5 \%)$, in comparison, exercised their freedom not to participate in any follow-up studies, indicating the principle of voluntary participation was implemented in the present study (Creswell, 2014).

\section{Data analysis}

The questionnaire data were recorded into SPSS 25 and analysed further to answer the research questions. Descriptive analysis was employed to answer the first research question on learners' SDL level. Independent Sample T-Test was employed to answer the second research question on whether there was any significant difference between female learners' SDL and male learners'. The sequence of the data collection and analysis could be seen in Figure 1.

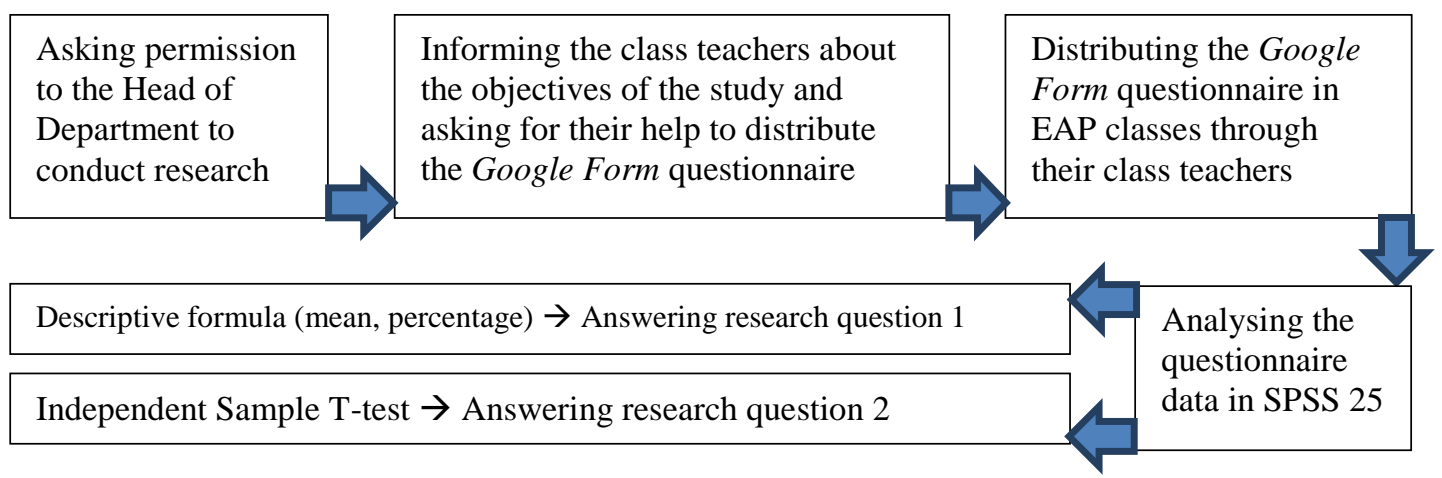

FIGURE 1 | The sequence of data collection and analysis

\section{RESULTS AND DISCUSSION}

\section{Results}

In total, 187 EAP learners participated in the present study. Of these 187 participants, 101 were female and 86 were male. The mean of the participants' age was 20.38 with the minimum age of the participants being 18 whilst the maximum being 25 . They were from various study programmes/departments. 60 participants $(32.1 \%)$ were from Management department, 48 (25.7\%) from Biology, 27 (14.4\%) from Architecture, 26 (13.9\%) from Product Design, 14 (7.5\%) from Accounting, and $12(6.4 \%)$ from Informatics. At the time of filling the online questionnaire, the participants, who followed the English lesson online, resided in various regions in Indonesia. 126 participants $(67.4 \%)$ were in Java, 18 (9.6\%) in Kalimantan, $13(7 \%)$ in Sumatera, 12 (6.4\%) in Sulawesi, five $(2.7 \%)$ in Papua, five $(2.7 \%)$ in Nusa Tenggara, two $(1.1 \%)$ in Bali, and the other six (3.2\%) in other islands/places.

\section{L2 learners' level of Self-Directed Learning (SDL) in English online class}

The composite result of learners' SDL could be seen in Table 1.

Table 1 | Learners' SDL Level

\begin{tabular}{lllll}
\hline Participants & Minimum & Maximum & Mean & Std. Deviation \\
187 & 44 & 75 & 59.18 & 6.11 \\
\hline
\end{tabular}

As seen in Table 1, the mean of the participants' total SDL level was 59.18. It indicated that on average, their responses were in 3.95, approaching "Agree" (4 points), indicating high SDL. Hence, it could be stated that in general, learners had a high SDL level during English online learning. More specific about the participants' responses in each item of the questionnaire, the mean of the participants' responses could be observed in Table 2.

Table 2 | The Mean of the Participants' Responses on the SDL Questionnaire

\begin{tabular}{ccr}
\hline Item Number & Mean & \multicolumn{2}{c}{ Std. Deviation } \\
1 & 4.39 & .78 \\
2 & 4.21 & .75 \\
3 & 3.82 & .92 \\
4 & 3.71 & .84
\end{tabular}




\begin{tabular}{rrr}
\hline 5 & 4.09 & .79 \\
6 & 4.51 & .61 \\
7 & 4.39 & .71 \\
8 & 2.54 & 1.13 \\
9 & 4.33 & .77 \\
10 & 4.18 & .82 \\
11 & 4.12 & .76 \\
12 & 3.57 & .88 \\
13 & 3.97 & .75 \\
14 & 4.18 & .70 \\
15 & 3.18 & 1.14 \\
\hline
\end{tabular}

As observed in Table 2, several items produced high mean scores of more than 4 , indicating a very high SDL level. Item number 6, "I hold myself responsible for my English learning," for example, yielded a mean score of 4.51, the highest among all the items. $95 \%$ of the participants either strongly agreed or of agreed with the statement. This finding suggested that the majority of the participants held themselves responsible for their learning progress. Furthermore, item number 1, "I believe that I can learn English, no matter how it is complicated," obtained a mean score of 4.39 . 86\% of the participants supported this statement. This indicated that they reported optimism in learning despite possible obstacles.Next, item number 7, "I must know clearly the objectives of the new subject to be learned," also obtained a mean score of 4.39. The statement was supported by $87.7 \%$ of the participants. This showed that it was important for these participants to know the learning objective or what was expected from them in learning.

Despite the high SDL level in general, interestingly, the two negative items, item numbers 8 and 15, yielded the lowest mean

scores of all. It indicated that learners, in contrast with their generally high SDL in the other items, reported their low SDL in these two items. Item number 8 , "Generally, I try to finish my homework at the last moment," obtained the lowest mean score of 2.54 . $49.8 \%$ of the participants supported this statement. In other words, $49.8 \%$ of the participants reported their tendency of working on tasks approaching deadlines. Furthermore, the second-lowest mean score was from item number 15, "The important thing is not what I learn in English class, but whether I've got a passing grade." It obtained a mean score of 3.18 with $25.7 \%$ of the participants endorsing the statement. This finding indicated that many participants considered achieving the passing grade of the English class more important than actual learning.

\section{Difference between female learners' SDL and male learners'}

An Independent Sample T-test was conducted to see whether there was a significant difference between female learners' SDL and that of male learners and the result could be seen in Table $\underline{3}$.

Table 3 | Results of Independent Sample T-Test of Female and Male Learners' SDL

\begin{tabular}{lccccccr}
\hline & \multicolumn{2}{c}{ Female $(\mathbf{N}=101)$} & \multicolumn{2}{c}{ Male $(\mathbf{N}=\mathbf{8 6})$} & \multicolumn{2}{c}{ T-test } & \multicolumn{2}{c}{ Sig. } \\
& $\boldsymbol{M}$ & $\boldsymbol{S D}$ & $\boldsymbol{M}$ & $\boldsymbol{S D}$ & $\boldsymbol{t}$ & $\boldsymbol{p}$ \\
Learners' SDL & 60.32 & 6.01 & 57.84 & 5.99 & .015 & & .90 \\
\hline
\end{tabular}

As observed in Table 3 , though the mean score of female learners' SDL $(M=60.32)$ was higher than that of male learners $(M=57.84)$, there was no significant difference between female learners' SDL and that of male learners $(p>.05)$.

\section{Discussion \\ L2 learners' level of Self-Directed Learning (SDL) in English online class}

The present study found that in general, the learner participants had a quite high level of SDL in the online learning setting. This result was in contrast with that of Allam et al.'s (2020) study in the Malaysian undergraduate university context. They found that their participants had a low level of SDL during the onset of online learning due to the Covid-19 pandemic. Though Allam et al.'s (2020) study was not conducted specifically in an L2 learning context, the comparison of both studies' results on different SDL level may indicate that learners in the present study were more prepared to face online learning situation than Allam et al.'s (2020) participants and thus were readier to self-direct their learning. It could be attributed to the present study's participants having experienced online learning mode for almost two semesters at the time of participating in the present study whilst Allam et al.'s (2020) participants were at the beginning state of experiencing an abrupt shift to online learning due to the pandemic. The adult learner participants, who were getting familiar with online learning due to the pandemic over time could finally formulate what worked for them and how they wanted to learn it (Slaouti et al., 2013), thus the high level of SDL. 
The result of the present study, furthermore, to a certain extent, corresponded to the results of several previous studies (e.g.: Rashid \& Asghar, 2016; Uz \& Uzun, 2018). For example, in an experimental study, $\underline{\mathrm{Uz}}$ and Uzun (2018) found that the experimental group with a blended learning mode of instruction showed significantly higher SDL than the control group with a face-to-face mode of instruction. Though blended learning in Uz's and Uzun's (2018) study and fully online setting in the present study were different, both shared a similarity in the way that both largely utilized technology in the instruction. Hence, the present study's finding corresponded to several authors' ideas positing that the use of technology could enhance learners' SDL (Rashid \& Asghar, 2016; Sumuer, 2018; Trimmel \& Bachmann, 2004). Sumuer (2018) argued that an online learning setting providing learners with collaboration opportunities, a flexible structure, as well as choice and control over learning facilitates learners to boost their SDL. In the present study, the EAP classes may have been designed, to a certain extent, to accommodate these as teachers may have had more experience in dealing with online instruction due to the Covid-19 pandemic in the previous semester. Hence, they may have been better equipped when designing the EAP class instruction. For example, the combination of synchronous and asynchronous modes of instruction conducted by the EAP teachers could give learners more flexibility to decide the time, way, and what to engage in learning (Milligan \& Littlejohn, 2014; Moorhouse, 2020; Plaisance, 2018). This could explain why the majority of learners considered learning their responsibility, showed optimism in learning despite difficulties and considered learning goals important to know beforehand, prominent SDL characteristics (Ayyildiz \& Tarhan, 2015).

The participants' responses in two negative items, however, showed the opposite from the general trend. They generally showed low SDL in these two items in which many participants reported procrastination and considered achieving passing grades (and so passing the class) more important than learning progress. The finding on procrastination among these participants was in line with the finding of a study conducted by Ozer (2011) in faceto-face instruction in which procrastination was widespread among undergraduate students. It indicated that the procrastination phenomenon was extensive among undergraduate students regardless of the mode of instruction. Additionally, in the online setting in the present study, learners may have more tasks from content classes in their respective departments. This could be a factor compelling learner to finish tasks in their EAP classes later. As for learners' prioritizing passing the class over learning, the Indonesian EFL setting could play an influencing role. In a context where English was constrained to classroom use like the Indonesian context, learners' perceived needs to master the language may not be as important as their desire to pursue other endeavors, for example, graduating on time. Thus, it could explain why learners considered passing the EAP class more important. Besides, Asian culture which generally considers "face" very important (Subekti, 2018) may contribute to the participants' tendency to prioritise grades as not passing the class and having to repeat the class, at times with juniors, could pose a threat to their ego.
Difference between female learners' $S D L$ and male learners' $S D L$

This study found that female learners had slightly higher SDL than male learners did. However, there was no significant difference between female learners' SDL and that of male learners. Several much earlier studies mentioned that foreign languages were traditionally female subjects (Clark \& Trafford, 1995; Graham \& Rees, 1995; MacIntyre et al., 2002) with females generally exhibited more positive attitudes towards learning. However, the finding of this study that no significant difference was found could indicate that it may not always be the case. Furthermore, specifically reviewed in relation to previous studies in SDL related to technology, the present study's finding corresponded to the findings of several previous studies in Asia (e.g.: Gokcearslan, 2017; Lee et al., 2017). A study conducted by Gokcearslan (2017) in a Turkish High School context found no meaningful difference between female and male learners' SDL with technology. A study by Lee et al. (2017) in Hong Kong also found that undergraduate students' use of computers for SDL was not affected by gender.

These relatively same findings may give some kind of support that the use of technology in language instruction could somehow make learners, regardless of gender, to be readier to self-direct their learning. It may even, to a certain extent, debunk the widespread "myth" in the L2 literature stating that L2 learning was more for female learners than for male learners. In the quite old, yet still relevant literature, it was posited that in situations demanding more efforts in using technological devices, male learners had more tendency to make an effort (Venkatesh \& Morris, 2000). This could partly explain why, unlike the results of studies in the face-to-face mode of instruction contexts favouring female learners as more superior in language learning, findings of several studies in online learning contexts tended to find no significant difference between the two groups of gender (e.g.: Gokcearslan, 2017; Lee et al., 2017), the present study's finding being one of them.

\section{CONCLUSION}

The present study has several contributions. First, the finding on learners' generally high level of SDL in the online learning setting at the time of the Covid-19 pandemic could indicate that with careful planning of instructional design of online instruction taking into account learners' study load, supporting gadgets, and available resources, this emergency online learning situation could be momentum for them to take more initiatives in their learning. Secondly, male learners who were generally viewed as less capable than their female counterparts in extensive L2 literature exhibited relatively the same SDL level as that of female learners in the present study's online learning context. As an implication, this finding also suggests teachers optimize the use of technology to facilitate male learners to show a more positive attitude towards and to be more interested in language learning.

Furthermore, several limitations should also be acknowledged. First, the nature of the self-report questionnaire inherently brought the consequence that the data obtained in this study relied on the participants' report. Second, these participants took EAP classes in their respective departments and as such, 
they received different instructions, though typical activities Gokcearslan, S. (2017). Perspectives of students on acceptance could be similar to a certain extent. Hence, it was difficult to attribute their high SDL level to very specific online classroom practices in class due to the quantitative nature of this study focusing on the large number, rather than an in-depth analysis of a phenomenon. Next, though this study involved a large number of participants, thus having the possibility of generalisation, it should be seen in limited contexts and conditions, for example, university contexts with sufficient infrastructure to conduct sufficiently well-designed online instruction.

Directions for future studies could also be suggested. The finding of no significant difference between female learners' and male learners' SDL in the online learning setting opens the possibility of further studies investigating gender role in technology-related L2 learning. It may also be worthwhile to investigate factors affecting learners' SDL through semistructured interviews. Researchers could further inquire about both internal and external contributing factors affecting their SDL in L2.

\section{ACKNOWLEDGEMENTS}

I would like to thank the Faculty of Education and Humanities of Universitas Kristen Duta Wacana for funding this study. My gratitude also goes to all the EAP teachers helping me to collect the questionnaire data and all the EAP learner participants of this study.

\section{REFERENCES}

Allam, S. N. S., Hassan, M. S., Mohideen, R. S., Ramlan, A. F., \& Kamal, R. M. (2020). Online distance learning readiness during Covid-19 outbreak among undergraduate students. International Journal of Academic Research in Business and Social Sciences, 1(5), 642-657. https://doi.org/10.6007/IJARBSS/v10i5/7236

Ayyildiz, Y., \& Tarhan, L. (2015). Development of the selfdirected learning skills scale. International Journal of Lifelong Education, 34(6), 1-17. https://doi.org/10.1080/02601370.2015.1091393

Basereh, N., \& Pishkar, K. (2016). Self-directed learning and self-efficacy belief among Iranian EFL learners at the advanced level of language proficiency. Journal of Applied Linguistics and Language Research, 3(1), 232 240.

Clark, A., \& Trafford, J. (1995). Boys into modern languages: An investigation of the discrepancy in attitudes and performance between boys and girls in modern languages. Gender and Education, 7, 315-325.

Creswell, J. W. (2014). Research design: Qualitative, quantitative, and mixed methods approach. Sage Publications, Inc.

Dornyei, Z. (2005). The psychology of the language learner: Individual differences in second language acquisition. Lawrence Erlbaum. of tablets and self-directed learning with technology. Contemporary Educational Technology, 8(1), 40-55.

Graham, S., \& Rees, F. (1995). Gender differences in language learning: The question of control. The Language Learning Journal, 11(1), 18-19. https://doi.org/10.1080/09571739585200061

Gray, D. E. (2014). Doing research in the real world (3rd ed.). Sage Publications, Ltd.

Henry, A. (2011). Gender differences in L2 motivation: A reassessment. In S. A. Davies (Ed.), Gender gap: Causes, experiences, and effects (pp. 81-102). Nova Science.

Israel, M., \& Hay, I. (2006). Research ethics for social scientists. Sage Publications.

Kemendikbud. (2020). Mendikbud: Keselamatan dan kesehatan insan pendidikan di masa pandemi jadi prioritas utama [Ministry of Education and Culture: Safety and health of all parties involved in education at the time of the pandemic is prioritised]. http://pgdikdas.kemdikbud.go.id/readnews/mendikbud-keselamatan-dan-kesehatan-insanpendidikan-di-masa-pandemi-jadi-prioritas-utama

Kim, T. Y., \& Kim, Y. K. (2016). The impact of resilience on L2 learners' motivated behaviour and proficiency in L2 learning. Educational Studies, 1-15. https://doi.org/10.1080/03055698.2016.1237866

Klingsieck, K. B. (2013). Procrastination: When good things don't come to those who wait. European Psychologist, $18(1), 24-34$.

Ko, H. S. (2018). Self-directed learning and English proficiency by Korean Learners. English Teaching, 73(1), 49-69. https://doi.org/10.15858/engtea.73.1.201803.49

Lee, C., Yeung, A. S., \& Ip, T. (2016). Use of computer technology for English language learning: Do learning styles, gender, and age matter? Computer Assisted Language Learning, 1-17. https://doi.org/10.1080/09588221.2016.1140655

Lee, C., Yeung, A. S., \& Ip, T. (2017). University English language learners' readiness to use computer technology for self-directed learning. System, 1-12. https://doi.org/10.1016/j.system.2017.05.001

Lu, H., \& Luk, J. (2014). "I would study harder if I was a girl": Gendered narratives of low-achieving male and highachieving female EFL learners. Journal of Language, Identity \& Education, 13(1), 1-15. https://doi.org/10.1080/15348458.2013.835571

MacIntyre, P. D., Baker, S. C., Clement, R., \& Donovan, L. A. (2002). Sex and age effects on willingness to communicate, anxiety, perceived competence, and L2 motivation among Junior High School French immersion students. Language Learning, 52(3), 537564.

Milligan, C., \& Littlejohn, A. (2014). Supporting professional learning in a massive open online course. The International Review of Research in Open and Distributed Learning, 15(5). https://doi.org/https://doi.org/10.19173/irrodl.v15i5.185 5 
Mondol, S., \& Mohiuddin, M. G. (2020). Confronting Covid-19 with a paradigm shift in teaching and learning: A study on online classes. International Journal of Social, Political and Economic Research, 7(2), 231-247.

Moorhouse, B. L. (2020). Adaptations to a face-to-face initial teacher education course 'forced' online due to the COVID-19 pandemic. Journal of Education for Teaching, 00(00), 1-3. https://doi.org/10.1080/02607476.2020.1755205

Oliver, P. (2003). The student's guide to research ethics. Open University Press.

Ortega, L. (2009). Understanding second language acquisition. Routledge.

Ozer, B. U. (2011). A cross sectional study on procrastination: Who procrastinate more? International Conference on Education Research and Innovation, 18(1), 34-37.

Park, K. Y., Sung, T. S., \& Joo, C. W. (2018). On the relationship between college students' attitude toward the Internet and their self-directed English learning ability. Journal of Korea Society of Computer and Information, 23(2), 117-123.

Plaisance, M. (2018). Online course delivery. In J. I. Liontas (Ed.), The TESOL encyclopedia of English language teaching (First Edit). https://doi.org/https://doi.org/10.1002/9781118784235.e elt0129

Polat, N. (2011). Gender differences in motivation and L2 accent attainment: An investigation of young Kurdish learners of Turkish. The Language Learning Journal, 39(1), 1941. https://doi.org/10.1080/09571730903545251

Rashid, T., \& Asghar, H. M. (2016). Technology use, selfdirected learning, student engagement and academic performance: Examining the interrelations. Computers in Human Behavior, 63, 604-612. https://doi.org/10.1016/j.chb.2016.05.084

Slaouti, D., Onat-Stelma, Z., \& Motteram, G. (2013). Technology and adult language teaching. In G. Motteram (Ed.), Innovations in learning technologies for English language teaching. British Council.

Subekti, A. S. (2018). An exploration of foreign language anxiety in the Indonesian university context: Learners' and teachers' voices. TEFLIN Journal, 29(2), 219-244.

Sumuer, E. (2018). Factors related to college students' selfdirected learning with technology. Australasian Journal of Educational Technology, 34(4), 29-43.

Sze-yeng, F., \& Hussain, R. M. R. (2010). Self-directed learning in a socioconstructivist learning environment. Procedia - Social and Behavioral Sciences, 9, 19131917.

https://doi.org/https://doi.org/10.1016/j.sbspro.2010.12. 423

Trimmel, M., \& Bachmann, J. (2004). Cognitive, social, motivational and health aspects of students in laptop classrooms. Journal of Computer Assisted Learning, 20, $151-158$. https://doi.org/http://dx.doi.org/10.1111/j.13652729.2004.00076.x.
Uz, R., \& Uzun, A. (2018). The influence of blended learning environment on self-regulated and self-directed learning skills of learners. European Journal of Educational Research, 7(4), 877-886. https://doi.org/10.12973/eujer.7.4.877

Venkatesh, V., \& Morris, M. G. (2000). Why don't men ever stop to ask for directions? Gender, social influence, and their role in technology acceptance and usage behavior. MIS Quarterly, 24(1), 115-139. https://doi.org/http://www.jstor.org/ stable/3250981

Zhu, M., Bonk, C. J., \& Doo, M. Y. (2020). Self -directed learning in MOOCs: Exploring the relationships among motivation, self-monitoring, and self-management. Educational Technology Research and Development. https://doi.org/10.1007/s11423-020-09747-8

Zoghi, M., Kazemi, S. A., \& Kalani, A. (2013). The effect of gender on language learning. Journal of Novel Applied Sciences, 2(4), 1124-1128.

Conflict of Interest Statement: The authors declare that the research was conducted in the absence of any commercial or financial relationships that could be construed as a potential conflict of interest.

Copyright (C) 2021 Adaninggar Septi Subekti. This is an open-access article distributed under the terms of the Creative Commons Attribution License (CC BY). The use, distribution or reproduction in other forums is permitted, provided the original author(s) and the copyright owner(s) are credited and that the original publication in this journal is cited, in accordance with accepted academic prac- tice. No use, distribution or reproduction is permitted which does not comply with these terms. 